2017-01-27

\title{
Determinants of financial performance of Islamic banks: An intellectual capital perspective
}

\section{Nawaz, T}

http://hdl.handle.net/10026.1/8627

\subsection{8/JIABR-06-2016-0071 \\ Journal of Islamic Accounting and Business Research}

All content in PEARL is protected by copyright law. Author manuscripts are made available in accordance with publisher policies. Please cite only the published version using the details provided on the item record or document. In the absence of an open licence (e.g. Creative Commons), permissions for further reuse of content should be sought from the publisher or author. 


\title{
Determinants of financial performance of Islamic banks: An intellectual capital perspective
}

\begin{abstract}
Purpose - The purpose of this paper is to empirically examine the effect of intangible resources i.e. intellectual capital (IC) on financial performance of 64 Islamic financial institutions (IFIs) operating in eighteen different countries for the period 2007-2011, while controlling for firm-specific variables viz. bank-size, level of risk, listing status, and firmcomplexity.
\end{abstract}

Design/methodology/approach - The required data to calculate different constituents of IC is derived from Bankscope database. Value Added Intellectual Coefficient (VAIC) methodology devised by Pulic is used to determine the impact of IC on financial performance of IFIs.

Findings - Results indicate a significant positive relationship between Value Added Intellectual Coefficient (VAIC) and accounting performance based on ROA. The results further indicate a significant positive relationship between accounting performance and capital employed efficiency (CEE) and human capital efficiency (HCE), but no significant relationship with regards to structural capital efficiency (SCE). Overall, the results suggest that value creation capability of IFIs is highly influenced by HCE and CEE.

Research limitations - The main limitation of the present study lies in its methodological tool, the VAIC methodology, which has been criticised by some researchers as not really measuring IC. Despite the inherent limitation of the VAIC methodology which relies on secondary data published in annual reports, it is still considered by some researchers as one of the best available tool to measure firms' IC in the absence of access to detailed internal information on IC.

Practical implications - The findings may serve as a useful input for Islamic bankers in managing their investments in IC within their institutions.

Originality/value - The main contribution of this paper is to use a previously little studied area, Islamic banking and finance, to identify the effect of intellectual capital on performance.

Keywords: Islamic financial institutions, Intellectual capital, Resource-based theory, Financial performance, VAIC. 


\section{Introduction}

Traditional economic theory describes the basic resources for a firm to operate in terms of the classic land, labour and other economic assets (Sullivan, 2000). However, in the knowledgeeconomy era, organizations worldwide have recognized that a firm's intangible resources are more likely to contribute to the firm attaining and sustaining superior performance (Eisenhardt and Schoonhoven, 1996). Therefore, effective management of intellectual capital (IC) has been acknowledged as the most important source of value creation and competitive advantage of the modern organizations, including the financial services industry. To compete effectively in today's knowledge-intensive era, financial institutions may need to embrace a new set of strategic priorities $(\mathrm{Li}, 2001)$ in order to survive and also to compete with powerful new players entering the marketplace such as the Islamic financial institutions (IFIs).

Research on IC has been one of the most prolific research domains in the management literature in the last two decades. Studies focusing on high-tech industries such as IT (Hsu and Wang, 2012), biotechnology (Hermans and Kauranen, 2005), and manufacturing (Tseng and Goo, 2005) have shown a significant relationship between IC and corporate performance. Lately, studies have shown a sustained interest in the services sector and specifically in financial institutions (Al-Musali and Ismail, 2014; Curado et al., 2014; El-Bannany, 2008; Murthy and Mouritsen, 2011; Mention and Bontis, 2013; Kubo and Saka, 2002; Nimtrakoon, 2015) in comprehending how IC impacts on performance. However, studies conducted within the financial sector have shown mixed evidence on the relationship between IC and performance of banks. Furthermore, there is a dearth of research that has looked at the impact of IC on performance of Islamic financial institutions. The present study seeks to contribute to the literature in the area by empirically examining the impact of IC on performance of IFIs. We used the Value Added Intellectual Coefficient (VAIC) and its sub-components, human capital efficiency (HCE), structural capital efficiency (SCE) and capital employed efficiency 
(CEE) developed by (Pulic, 2004) as proxies for IC. In a departure from prior research, our study is in a cross-country context.

The remainder of the paper is organised as follows. The next section presents a review of the literature and development of the hypotheses to be tested in the current study. Section 3 describes the research method employed followed by a discussion of the findings in Section 4 . The final section presents the concluding remarks.

\section{Background and Development of Hypotheses}

Stewart (2007) posits that every business relies increasingly on knowledge and old-fashioned experience. Added together, this knowledge is intellectual capital (IC) which can be defined as the sum of everything everybody in the company knows that will help to provide competitive edge in the market. According to Sullivan (2000), IC basically constitutes knowledge, lore and innovations while Sveiby (1997) describes IC as the knowledge, experience, employee intellect and knowledge resources stocked up in an organization's databases system processes, culture and philosophy. According to CIMA (2001), IC is the possession of knowledge and experience, professional knowledge and skills, good relationships, and technological capacities, which when applied will give organizations competitive advantage.

IC can be further broken down into various components. Edvinsson and Malone (1997) classified IC into human capital and structural capital. The former is grounded on the knowledge created and stored by a firm's employees, while the latter is based on the embodiment, empowerment and supportive infrastructure of human capital. Structural capital can be further divided into organizational capital (knowledge created by and stored in an organization's information technology systems and processes that speeds the flow of knowledge through the organization) and customer capital (the relationships that an 
organization has with its customers). Hsu and Wang (2012) simplifies that human capital can leave the firm whenever it desires since the firm does not own it. Structural capital, on the other hand, is knowledge that has been converted into something owned by the firm (e.g. patents). The present study adopts the classic sub-division of IC into human and structural capital proposed by Edvinsson and Malone (1997).

It is widely accepted that a firm's capability to innovate is closely tied to its intellectual capital (Subramaniam and Youndt, 2005). Accordingly, firms are viewed as the distributed knowledge systems composed of individuals who embody knowledge (Un and Cuervo-Cazurra, 2004). Equally, somewhat sophisticated structural mechanism is essential to transform the intellectual ideas into tangible assets. Such an environment is provided by the structural capital, which enables an organization to create and leverage knowledge. Strong structural capital will also have a supportive culture that encourages employees to try and learn new knowledge. In other words, it is important to recognise that human and structural capitals are interdependent i.e. the implementation of structural capital relies on human capital and the quality of human capital determines the quality of structural capital. At the same time, financial capital is also essential to run the business like well-oiled machines.

In the case of Islamic financial institutions, IC is highly significant due to the fact that the whole phenomenon of Islamic banking is based on the intangible intellectual ideology of Shariah, the Islamic religious law, which guides Islamic Economics. Under Shariah, IFIs are duty-bound: 1) not to deal with interest-based (riba) activities; 2) not allowed to undertake speculative (gharar) activities; and 3) prohibited from financing specific illicit (haram) activities. Besides, IFIs are based on trust; hence, safeguarding reputation, credibility and legitimacy are the alternative performance objectives for IFIs rather than attaining pure financial outcomes. Therefore, IFIs are expected not to cause moral hazard and suffer from agency problem. Furthermore, the risk sharing principle and real economic transactions 
backed by tangible asset, suggests clear differences in the funding and activity structures of Islamic and conventional financial institutions (Beck et al., 2013). Since IFIs came into existence to provide ethical/cooperative financial solutions to the society at large and are not subject to any particular ethical group, such institutions are expected to be more innovative in providing alternative banking solutions by exploiting their various intellectual capitals in order to gain competitive advantage and enhance firm performance. IFIs require a subsequently higher degree of intellectual capabilities, especially human intellectual capital for endorsement of product innovation. Hence, value creation in Islamic finance industry is a combination of human, structural and financial capital and it is important to examine which of the three components contributes most to the value creation of IFIs.

\subsection{Development of Hypotheses}

The resource-based view of the firm argues that differences in profitability across organizations can be explained by differences in their portfolio of resources and how these resources are articulated (Wernerfelt, 1984). According to Barney (1991), the resource-based theory recognizes intangible assets as critical factors in generating sustainable competitive advantage necessary for the creation of superior business performance. Markets around the globe have witnessed an industrial shift from being capital-intensive to knowledge-based. The traditional performance measures fail to measure and monitor multiple dimensions of performance as they concentrate almost exclusively on financial aspects of the organizations (Amaratunga et al., 2001). Therefore, new techniques are necessary to measure the value of intangibles and their impact on firm's performance. 


\subsubsection{Value Added Intellectual Capital and Performance}

The primary pursuit of any business is to create and maintain value (O'Cass and Ngo, 2011). The concept of value added (VA), which refers to the overall value creation efficiency of all resources a firm possesses, is increasingly viewed as an important variable in assessing performance. Various authorities argue that value creation in the knowledge-intensive sectors such as the banking industry require both IC and physical assets (Stewart 2007; Bontis, 1998; Pulic, 2004; Goh, 2005). On the other hand, the extent literature at times tend to treat the subcomponents of IC i.e. human IC and structural IC as completely independent construct, thereby losing sight of the whole IC. This is not to say that defining and understanding the subcategories of IC is not important but quite the contrary. In fact, developing theoretically based subcategories of IC is a necessity in advancing our ability to operationalize and understand the abstract and sometimes confusing concept. Youndt et al. (2004) posits that treating human IC and structural IC as discrete, unidimensional phenomena tends to simplify reality by not explicitly acknowledging the potential patterns of coexistence among these differing types of IC. Therefore, in order to fully understand how IC develops and drives performance, it may be helpful to look at an organization's overall profile of IC in the aggregate before independently focusing on individual parts.

Accordingly, it is expected that the higher a firm's aggregate stock of IC, the more successful the firm will be and the greater will be its competitive advantage. In other words, the higher the value added intellectual coefficient of IC that the IFI has, the higher will be its accounting performance based on ROA. Therefore, our first hypothesis is stated as follows:

Hypothesis 1: There is a significant positive relationship between VAIC and IFIs' performance

The extent literature suggests that IC is typically understood to consist of human IC, which is creative, and structural or organizational IC which consists of best practices. Murthy 
and Mouritsen (2011) argue that each of the intellectual capital elements viz. human IC and structural IC, has a fragile identity and causality, and therefore it has only limited individual power to increase creativity, or to consolidate best practice. Therefore, it is necessary to measure the contribution of each resource i.e. human IC, structural IC, and financial capital separately. Accordingly, we also measure the sub-components of VAIC viz. HCE, SCE, and CEE separately, to examine which of the three components contributes most to the value creation of IFIs.

\subsubsection{Human Capital and Performance}

Colombo and Grilli (2005) suggest that firms with greater human IC (i.e. higher education or skill) are likely to have better entrepreneurial judgment and as long as human IC continues to be developed, staff can improve their job performance and ultimately improve the firm's performance (Hsu, 2007). Human IC increases as staff accumulate specialized information, skills and know-how, which allow them to communicate efficiently and effectively, thus reducing decision-making errors, and improving performance (Luthans and Youssef, 2004). This inference also finds support in other literature streams. Human capital theorists (Becker, 1964; Schultz; 1961), for instance, simply reason that an increase in worker skills, knowledge, and abilities will most likely translate into increased organizational performance. In other words, human IC generates new ideas and techniques that can be embodied in production equipment and processes; this initiates changes in production and service delivery methods; and improves internal relations (between workers and management) as well as external relations (between customers, suppliers, regulators, and firm), and alternatively improves organizational performance (Berg, 1969). Likewise, Dakhli and De Clercq (2004) suggest that a firm's stock of human IC will influence its profitability. 
In the case of IFIs, human IC is important as employees are expected to not only have conventional knowledge and skills related to the provision of such services but also having good knowledge on Shariah as this will enhance the credibility and reputation of IFIs in the market place. Thus, our next hypothesis is as follows:

Hypothesis 1a: There is a significant positive relationship between HCE and IFIs' performance

\subsubsection{Structural Capital and Performance}

Structural IC provides an environment which enables an organization to create and leverage knowledge. An organization with strong structural IC will have a supportive culture that encourages employees to try and learn new knowledge (Florin et al., 2003). De Brentani and Kleinschmidt (2004) suggest that an organization's operation processes and the organizational commitment to sufficient resources will have a significant impact on performance. A similar suggestion is made by Youndt et al. (2004), who found structural IC to be typically associated with financial returns and Tobin's Q. Likewise, Hsu and Wang (2012) posit that structural IC, i.e. operations, procedures and the processes of knowledge management, propel organizations' value creation activities which in turn will have a positive effect on their performance. In other words, firms require advanced technologies to compete in today's fastpaced economyand greater care is needed to manage structural IC so that the required level of performance is achieved. Huang and Liu (2005), for example, employed multiple regression models to examine the relationships between innovation capital and information technology (IT) capital (i.e. structural IC) and firm's performance, and reported that investment in structural IC has a positive effect on performance.

IFIs adopt different structural process and system to track and record their transactions. Unlike the conventional banking system, penalty on late payment, for instance, is not credited into the account receivables. Such penalties are considered as interest and are subject to a 
charity account set for the benevolence loans and other charitable purposes. This requires development and investment in the structural processes that may affect their firm performance. Therefore, our next of hypothesis is:

Hypothesis 1b: There is a significant positive relationship between SCE and IFIs' performance

\subsubsection{Financial Capital and Performance}

Research generally explains that IC has to be contextualized by other resources including physical and financial ones (Youndt et al., 2004; de Castro and Sáez, 2008). At the crux of this research is that IC does have the positive agenda of growth where it is understood to bring financial capital forward. Yet, the dilemma is that IC as a resource is not only expensive but must compete with many other types of investments that emerge as part of organizational processes such as financial planning and budgeting. While prior research has identified difficulties in establishing credible, statistical relations between non-financial and financial performance measures (Ittner, 2008; Wyatt, 2008), Murthy and Mouritsen (2011) analysed the relationship between IC and financial capital and conclude that the relationship between IC and financial capital is complementary rather than causal. However, the study suggests that better firm performance is achievable subject to the combination of firm's IC and financial capital.

Most of the IFIs are based along the Arabian Peninsula, which is blessed with petrodollar. The powerful groups in the Gulf-region, particularly the Royal families, their extended families, and to a lesser degree those having close working relationship with them (Hudaib and Haniffa, 2009), own most of the wealth in the Gulf-region. This provided Islamic banking an opportunity to lure the huge sums of petrodollars amassed in Royal hands, as well as the small group of local capitalist élites, to benefit the wider society. However, the social impacts of such an arrangement remain unknown to date. What is known is that a 
major proportion of this wealth is channelled through IFIs for investment purposes as the clients seek investment opportunities that will not violate their religious obligations. IFIs offer such platform that brings huge sums of money into the Shariah-compliant business and subsequently, increases the physical and financial capital base of IFIs. The financial capital raised from shareholders and depositors must be managed efficiently as it is based on the Islamic concept of amanah (trust). Since no interest is involved in Islamic banking and profit is solely earned through employing capital in different projects, we expect the efficiency of capital employed to be positively associated with the overall performance of IFIs. Hence, our next hypothesis is;

Hypothesis 1c: There is a significant positive relationship between CEE and IFIs performance.

\section{Research Design}

The sample of IFIs in our study was selected based on the Bankscope database which has a unique collection of micro-level banking information for different countries and is widely used for international studies and policymaking (Demirgüç-Kunt and Detragiache, 1998). Initially, a total of 157 Islamic financial institutions (IFIs) representing 21 countries worldwide were identified. Since we dealt with a panel data for 5 years from 2007 to 2011, we filtered the database for data availability and selected a final sample of 64 IFIs operating in eighteen different geographical regions into three main groupings, namely, Asia, Europe and the Middle-East.

\subsection{Dependent Variable}

The dependent variable in our model is the performance of IFIs. Performance is operationalized in terms of the monetary terms that a firm receives in exchange for the price 
it pays for products or services (Hsu and Wang, 2012). This rationale is supported by the transaction cost theory (Williamson, 1985), which has dominated theoretical and empirical research in this area. Financial-based index such as return on assets (ROA) and return of equity (ROE) are traditionally employed to measure performance (Usoff et al., 2002). ROA gives an idea as to how efficient management is at using its assets to generate earnings, while ROE measures a firm's efficiency at generating profits from every dollar of net assets, and shows how well a company uses investment dollars to generate earnings growth.

These traditional accounting based performance measures have been criticized for their inadequacy in guiding strategic decisions. In particular, they do not consider the cost of capital incurred to fund the projects that generate these returns, and thus are severely lacking as instruments to guide managers in their quest for value-creating venues. In addition, they often fail to shed light on underlying causes for high or low performance of organizations (Bontis, 1998). However, some researchers (e.g., Stewart, 2007) argue that financialperformance measures, particularly ROA, are more appropriate in IC studies because they can be used to illustrate the financial value of intangible assets. While some studies have used more than one financial-performance measure i.e. ROA, return on sales, and ROE simultaneously (see Ho and Williams, 2003; Youndt et al., 2004), others have used single measure (e.g., El-Bannany, 2008; Hsu and Wang, 2012). Consistent with the latter stream of research, this study uses ROA as an accounting based performance measure of IFIs. Return on equity is ruled out because it is seen to be more sensitive to capital structure.

\subsection{Independent Variables}

The value added intellectual coefficient $\left(\mathrm{VAIC}^{\mathrm{TM}}\right.$ ) devised by Pulic (2000) forms the basis in measuring the efficiency of value added (VA) by a firm's total resources as well as each major resource component (Ho and Williams, 2003). VAIC ${ }^{\mathrm{TM}}$ is a composite sum of three 
indicators termed as: (1) Human Capital Efficiency (HCE), an indicator of the efficiency of VA by human capital resources employed; (2) Structural Capital Efficiency (SCE), an indicator of the efficiency of VA by structural capital; and (3) Capital Employed Efficiency (CEE), which indicates how much value is created for every monetary unit invested in financial or physical capital. Algebraically the $\mathrm{VAIC}^{\mathrm{TM}}$ relationship is formalized as:

$$
\mathrm{VAIC}{ }^{\mathrm{TM}}=\mathrm{HCE}+\mathrm{SCE}+\mathrm{CEE}
$$

Where $\mathrm{VAIC}^{\mathrm{TM}}=\mathrm{VA}$ intellectual coefficient; $\mathrm{HCE}=$ human capital coefficient; SCE $=$ structural capital coefficient, and CEE $=$ capital employed coefficient.

Value added (VA) of a firm is calculated by subtracting expenses from revenues. HCE is calculated by dividing a company's VA by its expenditures on human capital. SCE is calculated by dividing a company's investment expenses on structural capital by its VA. A firm's CEE is obtained by dividing its VA by the book value of the net assets. A high coefficient indicates higher value creation using the firm's resources including IC.

\subsection{Proxy Measures for Control Variables}

As knowledge creation, diffusion, and storage are inherently evolutionary in nature, the degree to which an organization develops its IC may vary across the sample. Accordingly, a number of firm-specific variables as suggested by the extant literature are used in this study (i.e. Al-Musali and Ismail, 2014; Beck et al., 2013; Nimtrakoon, 2015). Standard proxies used to measure the control factors in this study are formally defined as: (i) firm-size, proxied by the natural logarithm of total capital, (ii) level of risk, which is measured using leverage as a proxy, (iii) firm-complexity, using number of subsidiaries as proxy, and (iv) listing status, dichotomous, yes/no. 


\section{Empirical Results and Analysis}

\subsection{Descriptive Statistics}

Following prior studies (e.g., Chen and Chen, 2012) continuous variables are Winsorized at the $5^{\text {th }}$ and $95^{\text {th }}$ percentiles respectively in order to mitigate the effects for outliers. The data is normally distributed after removing the outliers. Table 1 provides the descriptive statistics viz. mean, standard deviation, minimum, maximum, standardised skewness and kurtosis, for the dependent and independent variables used in our models. Focusing first on the dependent variables in Table 1, it can be seen that the overall accounting performance of sampled IFIs is sound as indicated by ROA with a mean of 0.67 , suggesting that during the study period sampled IFIs were able to generate profit.

\section{[INSERT TABLE 1 ABOUT HERE]}

As for the continuous independent variables, it can be seen that the average mean of 3.93 for value added intellectual coefficient (VAIC) suggests that during the period 2007-2011, the sample IFIs were generally efficient in generating value from their intellectual capital. Descriptive statistics related to the segregated independent variables indicate that HCE, SCE and CEE all have positive means of 2.94, 0.7 and 0.19 respectively. This suggests that HCE remained the main value driver for IFIs during the study period, indicating the effective utilization of human capital.

For firm-specific control variables, it can be seen that the mean size of IFIs is 14.36. The results lend support to the findings of the earlier research (Khan, 2010, Beck et al., 2013), which documented the stability of IFIs during the recent financial crisis. Level of risk, measured using leverage as proxy has a minimum and maximum value of 4.37 and 77.99 respectively, indicating the risk diversity within the industry. 
Table 1 also presents the results based on Pearson's correlation. It can be seen that our variable of interest, VAIC, is positively correlated with accounting-based performance measures at 0.56. Similarly, all the sub-components of value added i.e. HCE, CEE and SCE, are positively related to ROA with the exception of SCE, which is positive but not significant.

Before running the regression, we conducted analysis of residuals, plots of the studentised residuals against predicted values and they indicate no problems of homoscedasticity and linearity. Residuals of standard tests on skewness and kurtosis indicated some problem with the normality assumption for four of the variables and we transformed the data accordingly using natural logarithm and cube root to get the best fit. To test the hypotheses developed in this study, we ran the following main regression model:

$$
R O A=\alpha+\beta 1 \text { VAIC }+\beta 2 F \text { Size }+\beta 3 \text { Risk }+\beta 4 \text { Sub }+\beta 45 \text { Listing }+\varepsilon \quad \text { Regression }
$$

Eq.

\subsection{Does Intellectual Capital affect financial performance of IFIs?}

Table 2 reports the results of the regression analysis based on accounting performance, ROA. We run the model four times, referred to as Model 1, 1a, 1b and 1c. Model 1 is our main regression model, which examines the association between accounting-based performance of IFIs and VAIC. Value added intellectual coefficient (VAIC) is found to have a significant ( $p$ $<0.01)$ positive relationship with ROA, thus supporting hypothesis 1 . This suggests that IFIs are efficient in creating value through their intellectual capital and financial capital resources. A significant negative relationship at $10 \%$ level can be seen between accounting based performance of IFIs and risk while all other firm-related control variables are not statistically significant in Model 1.

[INSERT TABLE 2 ABOUT HERE] 
In addition to the main model, three models are developed to measure the segregated impact of IC on accounting performance of IFIs. Models $1 \mathrm{a}, 1 \mathrm{~b}$ and $1 \mathrm{c}$ are the same as Model 1 but this time, the composite measure VAIC was substituted with the independent variables related to the three dimensions of VAIC viz. HCE, SCE, and CEE. Model 1a examines the association between accounting-based performance of IFIs and human capital efficiency. The results from Model 1a are reported in the fourth column of Table 2, which indicates significant positive relationship at $1 \%$ level between human capital efficiency and ROA, supporting hypothesis 1a. The results corroborate human IC as the primary source of value creation, which allows for better understanding of the hidden values of intellectual wealth (Subramaniam and Youndt, 2005). These findings are consistent with earlier studies (Goh, 2005; Mavridis and Kyrmizoglou, 2005; Mention and Bontis, 2013), which reported that human IC contributes both directly and indirectly to business performance in the banking sector.

Model $1 \mathrm{~b}$ examines the association between accounting-based performance of IFIs and SCE. The results in Model 1b, reported in the fifth column of Table 2, show no significant relationship between structural capital efficiency and accounting-based performance measure, thus not supporting our hypothesis $1 \mathrm{~b}$. However, this result does lend support to the argument that there may be trade-offs between the elements of intellectual capital, as proposed by Murthy and Mouritsen (2011), suggesting that multiple forms of intellectual capital may be unproductive. Consequently, not all investments in the elements of IC are profitable for IFIs (Youndt et al., 2004; Li, 2001).

Model 1c examines the association between accounting-based performance of IFIs and capital employed efficiency (CEE). Results in Model 1c, reported in the sixth column of Table 2, are similar to those of Model 1a but with a slightly higher coefficient. The results suggest a significant positive relationship at the $1 \%$ level between CEE and ROA, thus 
supporting hypothesis 1c. Firm-specific control variables are not significant with the exception of risk and listing status, which are both significant at the $1 \%$ level in the predicted direction.

The overall results are in agreement with previous studies (Al-Musali and Ismail, 2014; Curado et al., 2014; Nimtrakoon, 2015; Reed et al., 2006), which documented a positive relationship between IC and bank's accounting performance. Furthermore, our results indicate a significant positive relationship between financial performance and the variables, capital employed efficiency (CEE) and human capital efficiency (HCE), suggesting that ROA captures the value added intellectual coefficient from both CEE and HCE. Overall, our findings in the context of IFIs are consistent with previous research in the context of conventional banks by prior studies (Mavridis, 2004; Goh, 2005; Murthy and Mouritsen, 2011), that posit that the best performing banks are those that utilized their human intellectual capital and physical capital.

\section{Summary and Conclusion}

The main contribution of this paper is to examine the impact of intellectual capital (IC) on the accounting-based performance of 64 Islamic financial institutions (IFIs) operating in eighteen different countries worldwide for the period of 2007-2011, while controlling for firm-specific variables. Results indicate a significant positive relationship between Value Added Intellectual Coefficient (VAIC) and financial performance based on ROA. Our results further indicate a significant positive relationship between financial performance and the variables, capital employed efficiency (CEE) and human capital efficiency (HCE), suggesting that ROA captures the Value Added Intellectual Coefficient from both CEE and HCE. Overall our findings in the context of IFIs are consistent with previous research in the context of conventional banks. Islamic finance is still a rapidly evolving area, and new research is 
clearly needed to understand the key dynamics of such way of banking in the networked economy.

The study is not without limitations. The main limitation on the present study lies in its methodological tool, the VAIC methodology. Pulic (2004) argues that labour expenses are to be equated as investment in corporate human capital rather than an expense. However, if human capital is seen as an investment, the question arises as to whether it would be represented as an asset, which Pulic (2004) failed to address. Countering Pulic's view, it is argued that if human capital was an asset, labour expenses would have to be added to capital employed for the calculation of VAIC. Furthermore, Pulic (2004) considers the remaining operating expenses to represent structural capital as the residual of value added less human capital. The review of this project argues that Pulic's residual approach faces two major weaknesses. First, the residual approach assumes that all operating expenses are related to IC. Second, it may not capture all IC as favourable financial relations (i.e. relational capital) are omitted, which may be reflected in interest expenses rather than operating expenses. Despite these flaws, IC studies have continued to utilised the concept of VAIC (Goh, 2005; Kamath, 2007; Joshi et al., 2013; Nimtrakoon, 2015) and scholars still appreciate VAIC methodology (Andriessen, 2004; Bontis, 2001). Therefore, it should be noted that despite the inherent limitations of VAIC, the contributions made by the present study are still valid given data availability. While IC management can draw on internal data to examine IC, external data on IC value are rarely available for IC research. Therefore, IC research has investigated numerous approaches to find indicators of IC value from different perspectives. In the absence of internal data, VAIC methodology is still the best available tool to measure firms' IC. 


\section{References}

Al-Musali, M.A.K. and Ismail, K.N.I.K., 2014. Intellectual capital and its effect on financial performance of banks: Evidence from Saudi Arabia. Procedia-Social and Behavioral Sciences, 164(1), pp.201-207.

Amaratunga, D., Baldry, D. and Sarshar, M., 2001. Process improvement through performance measurement: the balanced scorecard methodology. Work Study, 50(5), pp.179-189.

Andriessen, D., 2004. Making sense of intellectual capital: designing a method for the valuation of intangibles. Routledge.

Barney, J., 1991. Firm resources and sustained competitive advantage. Journal of Management, 17(1), pp.99-120.

Beck, T., Demirgüç-Kunt, A. and Merrouche, O., 2013. Islamic vs. conventional banking: Business model, efficiency and stability. Journal of Banking \& Finance, 37(2), pp.433-447.

Becker, G.S., 1964. Human capital theory. Columbia, New York.

Berg, I. E. 1969. Jobs: The Great Training Robbery, New York, Praeger Publishers.

Bontis, N., 2001. Assessing knowledge assets: a review of the models used to measure intellectual capital. International Journal of Management Reviews, 3(1), pp.41-60.

Bontis, N., 1998. Intellectual capital: an exploratory study that develops measures and models. Management Decision, 36(2), pp.63-76.

Chen, S.S. and Chen, I.J., 2012. Corporate governance and capital allocations of diversified firms. Journal of Banking \& Finance, 36(2), pp.395-409.

Colombo, M.G. and Grilli, L., 2005. Founders' human capital and the growth of new technology-based firms: A competence-based view. Research Policy, 34(6), pp.795816.

CIMA 2011. Managing the intellectual capital within today's knowledge-based organisations: Technical Briefing.

Curado, C., Guedes, M.J. and Bontis, N., 2014. The financial crisis of banks (before, during and after): an intellectual capital perspective. Knowledge and Process Management, 21(2), pp.103-111. 
Dakhli, M. and De Clercq, D., 2004. Human capital, social capital, and innovation: a multicountry study. Entrepreneurship \& Regional Development, 16(2), pp.107-128.

de Castro, G.M. and Sáez, P.L., 2008. Intellectual capital in high-tech firms: The case of Spain. Journal of Intellectual Capital, 9(1), pp.25-36.

De Brentani, U. and Kleinschmidt, E.J., 2004. Corporate culture and commitment: impact on performance of international new product development programs. Journal of Product Innovation Management, 21(5), pp.309-333.

Demirgüç-Kunt, A. and Detragiache, E., 1998. Financial liberalization and financial fragility.

Edvinsson, L. and Malone, M.S., 1997. Intellectual Capital: Realizing Your Companyl's True Value by Finding Its Hidden Brainpower, New York, Harper Collins Publishers, Inc.

El-Bannany, M., 2008. A study of determinants of intellectual capital performance in banks: the UK case. Journal of Intellectual Capital, 9(3), pp.487-498.

Florin, J., Lubatkin, M. and Schulze, W., 2003. A social capital model of high-growth ventures. Academy of Management Journal, 46(3), pp.374-384.

Goh, C.P., 2005. Intellectual capital performance of commercial banks in Malaysia. Journal of Intellectual Capital, 6(3), pp.385-396.

Hermans, R. and Kauranen, I., 2005. Value creation potential of intellectual capital in biotechnology-empirical evidence from Finland. $R \& D$ Management, 35(2), pp.171185.

Ho, C.A. and Williams, S.M., 2003. International comparative analysis of the association between board structure and the efficiency of value added by a firm from its physical capital and intellectual capital resources. The International Journal of Accounting, 38(4), pp.465-491.

Hsu, L.C. and Wang, C.H., 2012. Clarifying the effect of intellectual capital on performance: the mediating role of dynamic capability. British Journal of Management, 23(2), pp.179-205.

Hsu, D.H., 2007. Experienced entrepreneurial founders, organizational capital, and venture capital funding. Research Policy, 36(5), pp.722-741.

Huang, C.J. and Liu, C.J, 2005. Exploration for the relationship between innovation, IT and performance. Journal of Intellectual Capital, 6(2), pp.237-252. 
Hudaib, M. and Haniffa, R., 2009. Exploring auditor independence: an interpretive approach. Accounting, Auditing \& Accountability Journal, 22(2), pp.221-246.

Ittner, C.D., 2008. Does measuring intangibles for management purposes improve performance? A review of the evidence. Accounting and Business Research, 38(3), pp.261-272.

Joshi, M., Cahill, D., Sidhu, J. and Kansal, M., 2013. Intellectual capital and financial performance: an evaluation of the Australian financial sector. Journal of Intellectual Capital, 14(2), pp.264-285.

Kamath, G.B., 2007. The intellectual capital performance of the Indian banking sector. Journal of Intellectual Capital, 8(1), pp.96-123.

Khan, F., 2010. How 'Islamic' is Islamic Banking?. Journal of Economic Behavior \& Organization, 76(3), pp.805-820.

Kubo, I. and Saka, A., 2002. An inquiry into the motivations of knowledge workers in the Japanese financial industry. Journal of Knowledge Management, 6(3), pp.262-271.

Li, F., 2001. The Internet and the deconstruction of the integrated banking model. British Journal of Management, 12(4), pp.307-322.

Luthans, F. and Youssef, C.M., 2004. Human, social, and now positive psychological capital management: Investing in people for competitive advantage. Organizational Dynamics, 33(2), pp.143-160.

Mavridis, D.G., 2004. The intellectual capital performance of the Japanese banking sector. Journal of Intellectual Capital, 5(1), pp.92-115.

Mention, A.L. and Bontis, N., 2013. Intellectual capital and performance within the banking sector of Luxembourg and Belgium. Journal of Intellectual Capital, 14(2), pp.286309.

Murthy, V. and Mouritsen, J., 2011. The performance of intellectual capital: mobilising relationships between intellectual and financial capital in a bank. Accounting, Auditing \& Accountability Journal, 24(5), pp.622-646.

Nimtrakoon, S., 2015. The relationship between intellectual capital, firms' market value and financial performance: Empirical evidence from the ASEAN. Journal of Intellectual Capital, 16(3), pp.587-618. 
O'Cass, A. and Ngo, L.V., 2011. Examining the firm's value creation process: a managerial perspective of the firm's value offering strategy and performance. British Journal of Management, 22(4), pp.646-671.

Pulic, A., 2004. Intellectual capital-does it create or destroy value? Measuring Business Excellence, 8(1), pp.62-68.

Pulic, A., 2000. VAIC TM_an accounting tool for IC management. International Journal of Technology Management, 20(5-8), pp.702-714.

Reed, K.K., Lubatkin, M. and Srinivasan, N., 2006. Proposing and testing an intellectual capital-based view of the firm. Journal of Management Studies, 43(4), pp.867-893.

Schultz, T.W., 1961. Investment in human capital. The American Economic Review, 51(1), pp.1-17.

Stewart, T.A., 2007. The wealth of knowledge: Intellectual capital and the twenty-first century organization. Crown Business.

Subramaniam, M. and Youndt, M.A., 2005. The influence of intellectual capital on the types of innovative capabilities. Academy of Management Journal, 48(3), pp.450-463.

Sullivan, P.H., 2000. Value driven intellectual capital: how to convert intangible corporate assets into market value. John Wiley \& Sons, Inc..

Sveiby, K.E., 1997. The new organizational wealth: Managing \& measuring knowledgebased assets. Berrett-Koehler Publishers.

Tseng, C.Y. and James Goo, Y.J., 2005. Intellectual capital and corporate value in an emerging economy: empirical study of Taiwanese manufacturers. $R \& D$ Management, 35(2), pp.187-201.

Un, C.A. and Cuervo-Cazurra, A., 2004. Strategies for Knowledge Creation in Firms. British Journal of Management, 15(1), pp.27-41.

Usoff, C.A., Thibodeau, J.C. and Burnaby, P., 2002. The importance of intellectual capital and its effect on performance measurement systems. Managerial Auditing Journal, 17(1/2), pp.9-15.

Wernerfelt, B., 1984. A resource-based view of the firm. Strategic Management Journal, 5(2), pp.171-180.

Williamson, O.E., 1985. The economic institutions of capitalism. Simon and Schuster. 
Wyatt, A., 2008. What financial and non-financial information on intangibles is valuerelevant? A review of the evidence. Accounting and Business Research, 38(3), pp.217-256.

Youndt, M.A., Subramaniam, M. and Snell, S.A., 2004. Intellectual capital profiles: an examination of investments and returns. Journal of Management Studies, 41(2), pp.335-361. 
Table 1

Correlation Matrix and Descriptive Statistics of Performance Measures and Continuous Independent Variables

\begin{tabular}{|c|c|c|c|c|c|c|c|c|c|c|c|c|c|c|}
\hline & Mean & Std. Dev. & Min. & Max. & Skew. & Kurt. & 1 & 2 & 3 & 4 & 5 & 6 & 7 & 8 \\
\hline 1. ROA & 0.666 & 2.374 & -3.81 & 3.809 & -0.483 & 2.245 & 1.00 & & & & & & & \\
\hline 2. VAIC & 3.925 & 2.018 & 0.361 & 7.03 & -0.289 & 2.214 & $0.5578^{* * *}$ & & & & & & & \\
\hline 3. $\mathrm{HCE}$ & 2.941 & 1.85 & -0.281 & 5.898 & -0.234 & 2.241 & $0.656^{* * *}$ & $0.9065^{* * *}$ & & & & & & \\
\hline 4. SCE & 0.698 & 0.219 & 0.267 & 1.052 & -0.441 & 2.8 & -0.0299 & $0.4111 * * *$ & $0.2147 * * *$ & & & & & \\
\hline 5. CEE & 0.191 & 0.156 & -0.094 & 0.488 & 0.059 & 2.487 & $0.566^{* * * *}$ & $0.56^{* * *}$ & $0.6076^{* * *}$ & -0.0558 & & & & \\
\hline 6. $\operatorname{lnFSize}$ & 14.361 & 1.557 & 10.787 & 16.836 & -0.674 & 2.736 & $0.3376 * * *$ & $0.3725 * * *$ & $0.4397 * * *$ & 0.0366 & $0.4516 * * *$ & & & \\
\hline 7. Risk & 42.504 & 21.858 & 4.369 & 77.986 & 0.009 & 1.973 & $0.1795^{* *}$ & $0.1685^{* *}$ & $0.204 * * *$ & $-0.1406^{*}$ & $0.4576^{* * * *}$ & $0.3397 * * *$ & & \\
\hline 8. Sub & 6.031 & 6.875 & 0 & 20 & 0.989 & 2.613 & $0.1494 * *$ & -0.0584 & -0.0424 & 0.0109 & 0.0477 & $0.2423^{* * *}$ & -0.036 & \\
\hline 9. Listing & 0.481 & 0.5 & 0 & 1 & 0.075 & 1.006 & $0.2479 * * *$ & $0.1269^{*}$ & $0.1893 * * *$ & -0.0481 & $0.1575^{* *}$ & $0.226 * * *$ & $0.1814 * *$ & $0.2753 * * *$ \\
\hline
\end{tabular}

Notes: Return on Assets $(\mathrm{ROA})=$ Net income available to stockholder / Total assets, VA = total revenue - total expenses, Human capital $($ HC) $=$ Total personal expenses, $\mathrm{HCE}=\mathrm{VA} / \mathrm{HC}$, Structural capital $(\mathrm{SC})=\mathrm{VA}-\mathrm{HC}, \mathrm{SCE}=\mathrm{SC} / \mathrm{VA}$, Physical capital $(\mathrm{CE})=$ Physical and financial capital employed $, \mathrm{CEE}=\mathrm{VA} / \mathrm{CE}, \mathrm{VAIC}=\mathrm{HCE}+\mathrm{SCE}+$

CEE, Firm-size $($ FSize $)=$ Log of total assets, Risk = Using leverage as proxy (Total debt/ Total assets), Firm complexity $=$ Total number of subsidiaries $($ Sub), and Listing status $($ Listing) $=$ dichotomous, yes/no. Pearson correlation: $* * * \mathrm{p}<0.01, * * \mathrm{p}<0.05, * \mathrm{p}<0.1$ 
Table 2

Cross-sectional Regression of ROA on VAIC, HCE, SCE, CEE and Control Variables

\begin{tabular}{|c|c|c|c|c|c|}
\hline & $\begin{array}{l}\text { Predicted } \\
\text { Sign }\end{array}$ & Model 1 & Model 1a & Model $1 b$ & Model 1c \\
\hline $\mathrm{N}$ & & 320 & 320 & 320 & 320 \\
\hline VAIC & + & $0.664 * * *$ & & & \\
\hline $\mathrm{HCE}$ & + & & $1.118 * * *$ & & \\
\hline SCE & + & & & -1.330 & \\
\hline CEE & + & & & & $11.76^{* * *}$ \\
\hline lnFSize & + & 0.0362 & -0.177 & $0.466 * *$ & 0.0452 \\
\hline Risk & - & $-0.0166^{*}$ & $-0.0222 * * *$ & -0.00610 & $-0.0371 * * *$ \\
\hline Sub & $+/-$ & 0.0274 & 0.0447 & -0.00672 & -0.0257 \\
\hline Listing & $+/-$ & -0.680 & -0.860 & -0.945 & $2.463 * * *$ \\
\hline Constant & & -1.596 & 1.013 & $-4.344 *$ & -1.683 \\
\hline R-squared & & 0.256 & 0.434 & 0.038 & 0.362 \\
\hline Adj. R-squared & & 0.243 & 0.431 & 0.025 & 0.352 \\
\hline
\end{tabular}

